\title{
Plaque Formation by Influenza Viruses in a Clonal Line of Porcine Kidney Cells
}

\author{
Shinobu Matsuda and Hideaki Yaoi \\ Biological Research Laboratories, ${ }^{*}$ Research and Develop- \\ ment Division, Takeda Chemical Industries, Ltd., Osaka
}

Matsdda, S. and Yaor, H. Plaque Formation by Influenza Viruses in a Clonal Line of Porcine Kidney Cells. Tohoku J. exp. Med., 1971, 103(2), 217-219

The plaque formation by several strains of influenza virus was investigated in a clonal cell line of procine kidney (PS, clone Y-15). Among strains tested, PR8, NWS, and Lee formed well defined plaques and showed a linear doseresponse relationship, while FMI and Adachi did not. The method of this plaque assay is reported. - plaque formation; influenza viruses; kidney cells

A number of investigators have reported the plaque formation with influenza viruses in various primary tissue culture cells (Kilbourne 1969). However, only two reports have dealt with this problem using either a clonal line of human conjunctival cells, clone 1-5C-4 (Sugiura and Kilbourne 1965) or a cell line G2 from human bone carcinoma (Hatano and Morita 1967). We succeeded in producing plaques with some influenza viruses in another cell line.

The clonal line of porcine kidney stable cells (PS, clone $\mathrm{Y}-15$ ) was made available by the courtesy of Dr. Inoue, Kyoto Univ. Following his report (Inoue and Yamada 1964) cell monolayers were usually established and ready for plaque assays. Five strains of influenza virus; PR8, NWS, FM1, Adachi, and Lee were tested. All viruses were used in the form of infected allantoic fluids.

After removing the growth medium and washing, cultures in each bottle were inoculated with $0.2 \mathrm{ml}$ of virus samples and kept at $37^{\circ} \mathrm{C}$ for two hours. Five milliliters of agar medium were overlayed. The basal overlay medium was made by mixing equal parts of $2 \%$ agar melted in distilled water with double strength Earle's balanced salt solution containing $1 \%$ lactalbumin hydrolysate, $0.2 \%$ yeast extract, and antibotics. Sodium bicarbonate solution (final concentration $0.3 \%$ ) was then mixed. Finally we added bovine serum albumin or calf serum or horse serum to this overlay medium. After 7 days incubation at $37^{\circ} \mathrm{C}$, plaques were stained with $0.5 \mathrm{ml}$ per bottle of neutral red solution $(1: 2,000)$.

Among five strains tested, PR8, NWS, and Lee formed plaques. Interestingly, the addition of bovine serum albumin to overlay medium was essential to produce plaques with Lee, and calf serum or horse serum was required for NWS, while PR8 gave rise to plaques with both kinds of sera and serum component. A

Received for publication, November 4, 1970.

* Director: Dr. K. Shimamoto. 
TABLE 1. Plaque titers of various strains of influenza viruses in PS $(Y-15)$ cells

\begin{tabular}{|c|c|c|c|c|c|c|}
\hline \multirow{3}{*}{$\begin{array}{c}\text { Type \& } \\
\text { strain }\end{array}$} & \multicolumn{4}{|c|}{ PFU per $\mathrm{ml}$} & \multirow{3}{*}{ Plaque size } & \multirow{3}{*}{$\begin{array}{l}\text { EIDII } \\
\text { per ml }\end{array}$} \\
\hline & \multirow{2}{*}{$\% *$} & \multicolumn{3}{|c|}{ Kind of serum in agar overlay } & & \\
\hline & & $\mathrm{BSA} \dagger$ & Calf & Horse & & \\
\hline A/PR8 & $\begin{array}{l}2 \\
5\end{array}$ & $\begin{array}{l}7.0 \times 10^{6} \\
9.5 \times 10^{6}\end{array}$ & $\begin{array}{l}2.5 \times 10^{5} \\
\text { Not tested }\end{array}$ & $\begin{array}{l}2.5 \times 10^{5} \\
\text { Not tested }\end{array}$ & $2-4 \mathrm{~mm}$ & 1. $7 \times 10^{9}$ \\
\hline A/NWS & $\begin{array}{l}2 \\
5\end{array}$ & $\begin{array}{c}\text { Not tested } \\
0\end{array}$ & $\begin{array}{l}\text { 3. } 0 \times 10^{5} \\
8.2 \times 10^{6}\end{array}$ & $\begin{array}{l}1.8 \times 10^{7} \\
1.1 \times 10^{7}\end{array}$ & $4-8 \mathrm{~mm}$ & 2. $1 \times 10^{8}$ \\
\hline Al/FMl & $\begin{array}{l}2 \\
5\end{array}$ & $\begin{array}{l}0 \\
0\end{array}$ & $\begin{array}{l}0 \\
0\end{array}$ & $\begin{array}{l}0 \\
0\end{array}$ & - & 1. $6 \times 10^{8}$ \\
\hline A2/Adachi & $\begin{array}{l}2 \\
5\end{array}$ & $\begin{array}{l}0 \\
0\end{array}$ & $\begin{array}{l}0 \\
0\end{array}$ & $\begin{array}{l}0 \\
0\end{array}$ & - & 5. $0 \times 10^{8}$ \\
\hline B/Lec & $\begin{array}{l}2 \\
5\end{array}$ & $\begin{array}{l}9.0 \times 10^{5} \\
1.6 \times 10^{6}\end{array}$ & $\begin{array}{l}0 \\
0\end{array}$ & $\begin{array}{l}0 \\
0\end{array}$ & ca. $1 \mathrm{~mm}$ & 5. $0 \times 10^{7}$ \\
\hline
\end{tabular}

* Serum concentrations contained in overlay medium.

$\dagger$ Bovine serum albumin.

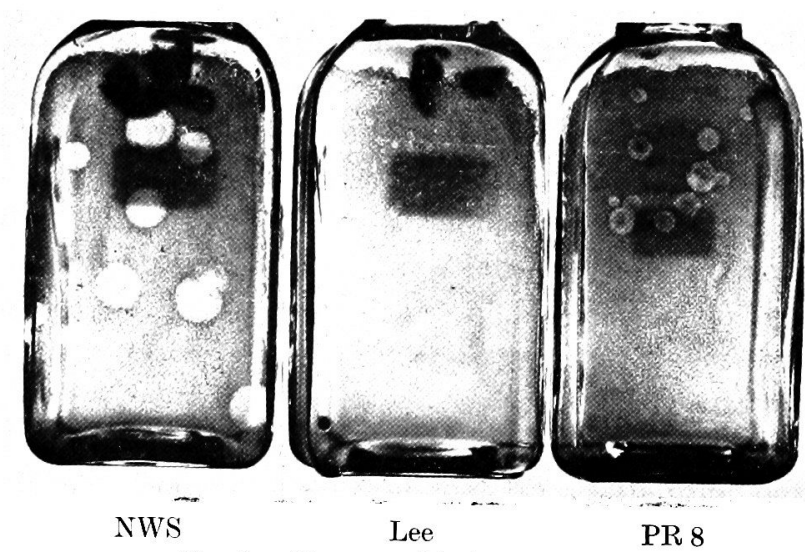

Fig. 1. Piaques of influenza viruses.

higher plating efficiency was obtained with $5 \%$ bovine serum albumin for PR8 and Lee. and with $2 \%$ horse serum for NWS (see Table 1)

There was a linear relationship between the concentrations of virus and the number of plaques. In the cases of NWS and PR8, visible plaques appeared on the 3rd day, and they continued to increase in size and number until the 7th day (Fig. 1). The plaques with Lee were the smallest, which measured only about 1 $\mathrm{mm}$ in diameter. Both plaques with PR8 and Lee always developed a "halo" appearance. Strains FM1 and Adachi did not form any plaques. Plaque titers 
calculated in PS cells were found to be lower as compared with $\mathrm{EID}_{50}$. Because PS (Y-15) cells are stable and easy to manipulate, they could be utilized favorably for experiments with some influenza viruses.

Lately, we found the report by Shimizu et al. (1969) indicating that the cell line from which PS cells clone $\mathrm{Y}-15$ was originally derived had been contaminated with an avirulent swine fever virus. Further studies are to be made to ascartain whether this contaminant played any role in the plaque formation by influenza viruses in PS cells clone $\mathrm{Y}-15$.

\section{References}

1) Hatano, M. \& Morita, O. Multiplication and plaque assay of influenza viruses in a continuous cell line $(\mathrm{G} 2)$ of human origin. Arch. ges. Virusforsch., 1967, 20, 305-313.

2) Inoue, Y.K. \& Yamada, M. Clonal line of procine kidney stable cells for assay of Japanese encephalitis virus. J. Bacteriol., 1964, 87, 1239-1240.

3) Kilbourne, E.D. Fundamental techniques in virology, edited by K. Habel, N.P. Salzman, Academic Press, New York \& London, 1969, pp. 158-160.

4) Shimizu, Y., Furuuchi, S., Hayashi, S., Kumagai, T. \& Sasahara, J. Procine kidney cell line persistently contaminated with avirulent swine fever virus. J. gen. Virol., $1969,4,625-628$.

5) Sugiura, A. \& Kilbourne, E.D. Genetic studies of influenza viruses. Ir. Plaque formation by influenza viruses in a clone of a variant human heteroploid cell line. Virology., $1965,26,478-488$. 